\title{
Back to the future: Thoughts about development and the future of missiology
}

\author{
Alawode, Akinyemi O \\ North-West University \\ akinalawode@gmail.com
}

\begin{abstract}
Missiologists have spent a lot of time since the 1990s in debating issues such as postmodernism, paradigm changes, etc. For the growing majority of Christians in the world (in Africa), pervasive poverty and the resultant need for community development seem to be more pressing. How and where will our people get their everyday needs? We should return to the debate of the 1970s and 1980s about the preferential option for the poor - churches, mission agencies and academics have too easily forgotten about this. Community development should therefore return to the top of the missiological agenda again. Missiologists have left development to the "experts" too easily. Faith communities and their leaders mostly know better than any others what kind of development is needed; faith communities are often the only credible and workable social institutions left in many areas; and community development is a fundamental dimension of Christian mission. There are signs that academics are beginning to be aware of this reality, so a call seems to be in order for missiologists to go "back to the future" by integrating the preferential option for the poor, the need for community development, and missiological praxis again.
\end{abstract}

\section{Keywords}

Christian mission, development agenda, faith communities, poverty poor people

\section{Introduction}

When considering the prospects of any subject, such as the future of Missiology, there are two well-known idiomatic sayings (in various languages), which must be kept in mind. In the first place, the reminder that we cannot know where we are going if we do not consider where we come from. The past thus looms large in any consideration of the future. In the second place, the admonition that those who refuse to learn the 
lessons, which our previous history teaches us, are doomed to repeat all the historical mistakes made on our journey. Again, the past looms large. It is in my awareness of the aptitude of these two sayings for any human community, also the community of Christian missiologists, that I present this paper, titled "Back to the future".

The choice of this topic implies certain limitations in my interpretation of the topic. It implies that the article considers the place and role of development ${ }^{1}$ in the history of mission and Missiology as an important indicator of the future wellbeing of Missiology. It also implies that the writer do not consider himself capable of presenting a universal analysis of the future of Missiology; since the research chose specifically for a contextual approach, this limits it analysis to (parts of) Sub-Saharan Africa (SSA). It is also quite obvious that one cannot consider twenty centuries of historical developments in one article, so the article has to choose a period: The researcher prefers to deal mainly with developments in relation to God's mission since the 1960s. This approach sets the limits for my discourse in this paper.

\section{Mission/Missiology and development: A brief survey of history}

As stated above, the article is aware that there is no univocal definition of development; and my own understanding will be discussed more extensively below. Here the article wants to state its conviction that, as Bosch (in Saayman 1992:44) indicated; development in general in the context of Christian mission finds its roots in Christian empathy with people in dire need. Bosch then referred to a study by Von Harnack (1962:147-198), which lists an impressive number of examples from the first three centuries of Christian history of such Christian empathy leading to what we can broadly call development today. One can therefore argue that development as a dimension of Christian mission and Missiology (as we understand it today) has its roots firmly in the history of the outreach of the Christian community since its very beginning ${ }^{2}$. This pattern was repeated

1 The author considers development to be a complex and, indeed, contested phenomenon, and will obviously describe his own understanding more fully in the rest of the paper.

2 Bosch (in Saayman 1992:44) refers to the well-known reality that the first hospitals in Europe grew out of this ministry. Churches in Europe also became involved in some of the earliest attempt at providing education to equip people to deal with everyday life. 
in SSA, Asia and elsewhere during the modern Western mission movement in the eighteenth and nineteenth centuries (Bosch in Saayman 1992:45). So in a very general way one can state that some form of development was an integral dimension of Christian mission from the earliest years.

Moreover, the article chooses to deal especially with the situation since around 1960s (in other words, the years post World War II). The years after World War II (1939-1945) brought great changes to self-understanding in the Western colonialist powers, as well as their relationships to their (previous) colonies. As Bosch (1979:177) describes the context of the first post-war meeting of the International Mission Council (IMC) in 1947 in Whitby, the delegates realised that one world (the old, pre-war Western Europe) was dying, while the rest of the world was going through birthpains in an attempt to bring a new world into being. Mission, at least as it was represented in the IMC, was therefore characterised by a new realisation of its bond with the world. This brought new emphasis on the old link between mission and development. ${ }^{3}$ This led to the fact that "development" was indeed regarded as the key concept at the momentous Uppsala Assembly of the World Council of Churches (WCC) in 1968 (:190). ${ }^{4}$ In terms of Bosch's analysis, this was therefore, not simply a contextuallyinspired development - it was the result of the growth of a new, specific spirituality (:191): a spirituality this article wish to describe as characterised by a compassionate life in the social justice tradition (Foster in Kritzinger \& Saayman 2011:190). This missionary responsibility to participate in the struggle for justice and human dignity (which could mainly be brought about through participation in development) was especially strongly emphasised at the WCC Assembly in Nairobi, Kenya in 1975 - an assembly characterised by Saayman (1980:119-127) as the beginning of a new direction (especially in terms of overcoming the Ecumenical-Evangelical confrontation).

3 The authors remembers Lesslie Newbigin mentioning in an address how, after the Second World War, in his position in the IMC, he had to become used to the priority of mission-as-(development as)-Inter-Church Aid, over mission-as-evangelisation-andchurchplanting. It is important to note that development understood in terms of the Western political economy (especially as incarnated in the Bretton-Woods Institutions) was the reigning interpretation in those days.

4 This was not caused only by the world situation - theological developments, especially the growth of the Theology of the Apostolate under the influence of Hoekendijk also played a very important role (Bosch 1979:178-180;190). 
At this stage of the debate the meaning and content of the word development was rather one-sidedly determined by First World theology, sociology and economics. However, by the late 1960s and early 1970s these established concepts (development and Christian mission) were being questioned under the growing influence of input from Third World Liberation Theologies (Latin American, African and Asian - Kritzinger in Saayman 1992:280). This played a role of growing importance in shaping the direction and content of the debate over what the meaning and content of development should be. Liberation Theologians from the three continents mostly colonised (South America, Africa and Asia) were clearly expressing their disillusionment with the fruits of development, propagating the term liberation to replace it. To simplify a very complex debate, one can say that they were stating: surely, our people need development - but what kind of development? Who decides what is most urgently needed? And, very important: who sets the agenda when we are discussing development schemes? (Cf. Kritzinger in Saayman 1992:280-282). There was good reason to ask these questions, because by the 1980s it was clear that the great postWar expectations about the contribution of development, also in mission circles, were not going to be realised. Perhaps the two most obvious reasons for the general failure were the introduction of unsuitable schemes, and corruption on a tremendous scale in the allocation and utilisation of the funds (Saayman 2003:69-71). There was another motivation, though, which was true especially in relation to Africa. Africa had in those days seldom been provided the opportunity "to interpret and present itself on its own terms to the rest of the industrialised world" (Saayman 2003:58). It is generally acknowledged today that during the Cold War era (more or less post-World War II until 1989) the "major powers" of the industrialised world viewed their involvement in Africa (also in terms of development funding) mainly in terms of their perceived strategic interests, for example their vested interests in the natural resources of some African Countries. So by the early 1990s the failure of many of the well-meant development schemes, as well as the growing popularity of Liberation Theologies, in the context of post-Cold War globalisation led to a shift in the debate signifying the waning importance of the established meaning, scope and 
role of development in the missiological debate. ${ }^{5}$ It is the paper's contention that in any consideration of the future of missiology, development must return to its rightful place of priority, especially in SSA. But there is an important provision here: it must be development as described by Africans themselves - it cannot simply be a re-imposition of an imported model.

This brings us to the next point in our argument: what dimensions should characterise our missional understanding of development today and in future?

\section{Characteristics of missional development today and in the future}

In the first place we need to rally around a common understanding of development, which is practical, useful and sustainable in SSA. This implies the following:

\section{Several lenses on the definition of development}

In the first place the article wishes to state very clearly that it's aware that development is a complex issue. It refers to "a complex world of institutions and ideas, one that is in flux, representing widely different approaches" (Marshall 2011:215) that can be reflected upon using multiple lenses. Thus, development or lack of it manifests itself in different dimensions that also need various lenses for the relevant assessment of development needs in any community. Burkey (1993: 35-39), who claims that development needs can be divided into at least four sub-divisions, namely, human (personal), economic, political and social development needs.

\subsection{Human (personal) development}

Human (personal) development is a process by which an individual develops self-respect, and becomes more self-confident, self-reliant, cooperative and tolerant of others through becoming aware of his/ her shortcomings, as well as his/her potential for positive change (ibid). This takes place through working with others, acquiring new skills and knowledge, and through active participation in the economic, social and

5 The discussion of the failure and the resultant waning of interest in issues of development in Saayman 2003:69-71. 
political development of the community. According to Oyedepo, who says (2005:7), "Until something changes within you, nothing changes around you. Every change begins from within. Without a change within, there can never be a change without". ${ }^{6}$

\subsection{Economic Development}

Economic development is a process by which people through their individual or joint efforts boost production for consumption and to have a surplus to sell for cash. This means that the returns to the activity must be greater than the cost, that is, the activity must be profitable. The flipside of production is marketing /selling - there can be no cash profits without available markets. So, economic development also includes developing markets. It also means that some of the surplus produced must be reinvested in the same activity or in profitable new activities (Oyedepo 2005:7).

\subsection{Political Development}

There is disagreement among analysts about political development in Africa. Debate over the meaning of political development is not confined to those concerned with Africa, of course. Once the question, what does political development mean? Or reformulated as, what do we mean by political development?

However, Swart (2003:405) says political development is a process of gradual change over time in which the people increase their awareness of their own capabilities, their rights and their responsibilities and use this knowledge to organize themselves so as to acquire political power in order to participate in decision-making at local level, choose their own leaders and representatives at higher levels of government, plan and share power democratically; and create and allocate communal resources evenly and efficiently among individual groups.

\subsection{Social Development}

The author regards social development as a process of gradual change in which people increase their awareness of their communal capabilities and common interests, and use this knowledge to analyse their needs;

6 It is of course equally true that no change springing from within the human "heart" can be sustained without changes brought about in the context. 
find solutions; organise themselves for cooperative efforts; and mobilise their human, financial and natural resources to improve, establish and maintain their social services and institutions within the context of their own culture and their own political system (Burkey 1993: 39). Therefore, social development should lead to empowerment and from a Christian perspective, the aim of holistic development (human, social, economic, political) should be to form human beings "who understand and appreciate their integral role in society as both Christians and good and responsible citizens" (Mulafulafu in Nkunsane 2010:76), in line with their Christian vocation to promote Gospel values. Such human beings must also be empowered to grasp the responsibilities of their integral role in society as good and responsible citizens.

\section{Holistic human development}

The author chooses to characterise his understanding of missional development as holistic, human and sustainable. It is human because, as Burkey (1993:34) observes, it is very important to keep in mind that development concerns people; it affects their way of life and is influenced by their conceptions of the good life, as determined by their culture. Development is not just a question of infrastructural projects such as schools, clinics, roads and dams as some people seem to think. Development means a process of enabling people to accomplish things that they could not do before - that is, to learn and apply information, attitudes, values and skills previously unavailable to them. Development, therefore, has to do with the realisation of adequate capacity (human resources) present in every community. Development depends a lot on human knowledge (mental wealth) and skills, and where this knowledge and these skills are inadequate to the task in hand, development will be thwarted. The development of human resources must include cognitive and affective development, physical development and the development of suitable attitudes and world-views. Development should be sustainable because it needs to fulfil present human needs without exhausting the earth's finite resources, thus endangering the lives and opportunities of future generations (Bullon 2007:94). Quaddus (2004:115) defines sustainable development as a process of development, which meets the needs of the present without compromising the ability to meet those of the future. 
However, according to Elliot (2006:9), sustainable development should also be understood as literally referring to maintaining development over time. She further argues that sustainable development is fundamentally about reconciling development and the environmental resources on which society depends (Elliot 2006:46). This is of special importance in SSA, where the major basis for development often is the exploitation of (finite) mineral resources.

Development should also be holistic, or, as Evangelicals at Wheaton in 1983 described their holistic understanding of development, "transformative" (Bullon 2007:96). It is now recognised that social sciences and related disciplines help us understand what is at stake when we talk of "social transformation" and its connectedness with holistic spirituality. Missional development will seek integration at every level. Theorists and practitioners need to understand and recognise that development involves the permanent and existential /continuous relationships between and among human beings, with our natural and social environment, and with the Divine.

\subsection{Integrating understandings of Christian mission and development}

How can one integrate such an understanding of development with Christian mission and missiology? In order to develop such an integrated approach, it is not only the concepts of development that must be changed; our understanding of Christian mission itself will also have to change. This is more necessary considering both bad and good history of the entanglement of colonialism and mission in Africa. In this respect an article by Philip Wickeri, "Towards a kenosis of mission: emptying and empowerment for the church and for the world" is helpful. This article was published in a volume of essays in honour of D Preman Niles, titled Scripture, community, and mission, published in 2003 by the Christian Conference of Asia (CCA) (Wickeri ed. 2003:342-348). Wickeri quotes a document of the CCA titled, "The people of God among all God's people", which states the following: "We understand that the mission of the Church, amidst all its ambiguities and the burden of history, is continually recast by communities which seek to shape their lives in light of the promise of the gospel". Wickeri (ibid) goes on to say that the first major shift necessary for such a new approach, is the need to accept that "mission begins with powerlessness, not power". This is why he uses the term kenosis, because his interpretation of the Christian 
kenosis implies both "emptying and empowerment". Understood in this way, he argues that the biblical text then is not simply regarded as "an anchor of tradition", but can indeed become "a springboard for faith and action". So he does not see kenosis leading to a defeatist and negative mindset, but rather to a "theology of servant hood". This implies that "salvation and well-being are attained not by conquest or by domination of the other, but by self-effacement and by self-giving love" (ibid). It is in this spirit we believe that mission praxis should be constructed for empowering the poor in order to help them alleviate their poverty. How can this be achieved?

In the first place, it is essential to understand poverty in SSA. In an article titled "Linking political participation, democracy and human rights", the Zimbabwean, Saki (in Kaulema 2010:1-14), concludes that poverty is in itself "a state of powerlessness and inability to influence decisions and change". Poverty has become a pervasive reality that, in Ndungane's words (1998: xii), "imprisons individuals and whole communities, robbing them of their ability to live with dignity and self-respect". As such it indeed poses a serious threat, "undermining political stability, social cohesion and the environmental health of the planet" (Ibid; italics mine). So poverty in Africa cannot be contained geographically - it threatens people everywhere. This disempowering, alienating and undermining effect of poverty, in my opinion, can be experienced in many communities in Africa. Chiware, in Kaulema 2010:15-28 an article entitled "Obstacles to political participation in Zimbabwe and recommendations for improvement" ascribes this powerlessness partly to "the absence of adequate channels for participation. Citizens must be continuously engaged in governance issues and processes". We think that the churches, through their participation in mission, can be used to provide both the motivation for engagement (empowering) as well as the channels of participation. Nkunsane developed this idea further by analysing the involvement of the Roman Catholic Commission for Justice and Peace in the Archdiocese of Harare in his article on "Empowering community for active and objective engagement" (in Kaulema 2010:76-84). He emphasises the goal of this commission to form "persons who understand and appreciate their integral role in society as both Christians and good and responsible citizens" with a calling "to promote Gospel values". Our opinion is that many churches in Africa have not done enough in this regard. This is more important if one considers the 
statement of Shylet (in Kaulema 2010:72) that public participation is made easier through institutions, which are nearer to the people and can react rapidly to arising challenges.

In many African countries, churches are the social institutions, which are not only close to the people, but which are also still functioning properly and retain credibility among people who have become disillusioned with corrupt and dysfunctional political and economic institutions. In this regard the words of Marshall (2009:212-233) are very helpful. She talked about the establishment of the World Faiths Development Dialogue and also writes about development issues in the Third World based on her experience in global institutions such as the Bill and Melinda Gates Foundation, the World Bank, etc. So her thinking on development issues provides useful guidelines on what the latest thinking is, as well on what works in practice and what not. We find her statement about "disconnects and tensions around religion and development" useful:

International affairs actors generally, and the development community more specifically, are considering, in diverse ways, their relationships with religion, from both practical and theoretical perspectives. Faith inspired actors and institutions, for their part, are rethinking relationships with many public programs and institutions.

In this regard she mentions the establishment of the World Faiths Development Dialogue by the World Bank, for example (:217). It seems to the researcher it is the right time; therefore to consider how African churches in their mission can start to help alleviate poverty in the communities they serve through transformative and holistic development programmes.

It is in light of this argument that this study urges for a new (re-)integration of development and Christian mission and Missiology.

\section{Focal points}

Having provided a brief overview of the historical links between Christian mission and development, as well as a brief overview of our understanding of the integral link between mission and development, the author wishes to conclude by briefly indicating two essential focal points in the relationship. What the article had provided so far dealt mainly with the "back" in the 
title (history, in other words). In this section this study wants to focus specifically on the "future" part.

\subsection{Who sets the agenda?}

I sketched the historical trends of the concept of development and Christian mission (1960s-1970s), and in the heyday of the debate development was defined in terms prescribed by Western scholars and theologians the West or First World set the agenda. Such an approach today and in future may not always succeed. As Saayman (2003:63-64) indicates, issues such as autonomy, indigence, inculturation and contextualisation are too important in the relationship today to simply accept Western leadership in structuring the debate. In this respect it is very important to point out that the debate of the 1960s-1970s took place before the concepts of contextualisation and inculturation ${ }^{7}$ had taken pride of place in the missiological debate. We referred above to the reality that Africans are convinced that they have seldom been provided the opportunity "to interpret and present [themselves] on [their] own terms to the rest of the industrialised world" (:58).

The debates about inculturation and contextualisation have helped Africans to overcome this handicap to some degree. If Africans set the agenda, development will have to be founded in the community itself, rather than in a governmental institution or NGO (non-governmental organisation). This implies that needs are defined locally, and that development schemes should be smaller, rather than bigger. This is why this article referred above to the reality that the best-functioning social institution close to the local community still functioning properly in SSA is the church in its various local lives. It is useful to repeat what the author said earlier on, why the church is the correct channel to use: it is close to the people, and knows what their needs are; it is widely trusted in an atmosphere where corruption is rampant; although there are corrupt leaders in the church as well, some of them embezzle church funds at will, but still the church is more accountable than any other social institution be it political or economic institutions in

7 A fuller description of our understanding of these concepts can be found in Saayman 1992:12-14; Kritzinger \& Saayman 2011:3-6; and Bate 1995 passim. In general we believe that contextualisation is used mainly in Protestant theology, and inculturation is the term mainly preferred by Roman Catholic theologians. 
SSA. According to Saayman (2003:72) development has a better chance of being successful in Africa if it is driven by the oikos, rather than the polis; and the oikos in SSA is incarnated in the local faith community rather than in the metropolitan socio-political community.

\subsection{Empowerment}

Empowering individuals and local communities is the second focal point in the debate about mission and development in SSA in future.

The epistemological priority of the poor must then, in my opinion (cf. Alawode 2013:6-10), enlighten my understanding of a theological perspective on empowerment. Empowerment addresses the lack of participation by people in their own development. This implies that one does not understand church involvement in combating poverty, as something the church must do for the poor; the church in mission should rather help individuals and groups discover ways and means to help themselves (Nkunsane 2010:82). People who do not participate in their own development do not have a say in their own future.

This contributes to what Chambers (1997:112) calls "powerlessness." Often these people are the poor and the marginalised. Empowerment has to do with personal participation - people being fully employed in achieving social progress and development: people in general and the poor in particular have to be involved with how life is organised around them (:76). Simply put, empowerment is capacity building on the individual and community level, which allows individuals to accomplish their full redemptive potential. The entire issue of empowerment has strong evangelical implications. If power means anything, given the human condition, it means transformation of lives through the energy of the gospel (Pannell 2002:15). If Jesus preached the gospel to the poor as a certification that he was the Promised One, then that act was more than words. It meant that he was part of the proclamation and that he lived in solidarity with the people. Empowerment reflects a transformation of minds as we understand and interpret a verse such as Romans 12:2. It has been argued that worldview as the total complex of beliefs, cultural practices and norms held by people affects ideas and ideas have consequences. It has also been argued that physical conditions alone do not dictate poverty; but that poverty also comes from a marred identity and a web of lies that blinds people on both personal and cultural levels. Thus empowerment needs to facilitate the ability 
of people to think in a Christian way (Miller 1998:73) in every area of life (Mk 12:29-30; Rom 12:2; 2 Cor 10:5). Empowerment must be an integral part of development if we are to go far towards a better future. Going far together is not just about the teaching of techniques, but the restoring of identity, of trustful collaborative partnerships, of working together in community and of transformation in all aspects of life. This transformation begins, in our understanding, on the inside, at the level of beliefs and values and moves outward to embrace behaviour and consequences (Miller 1998:73). The goal in development should be nothing short of a gospel-inspired transformation. As Nkunsane (2010:77) formulates it, "our engagement as Christians [in development] is meant to infuse the values that uphold the dignity of all of God's creation, especially all individual human beings".

\section{Conclusion}

Considering the main argument of this article regarding the place of development in the history of Christian mission, the author don't have alternative than to go against those observers, who perhaps argue that many development schemes in Africa have failed so spectacularly, that Christian mission would do better to stay out of the discussion, as mission and Missiology have very little to contribute in any case. As stated above the author differs from such an approach because it obvious that Africans mostly are delighted and resourceful people who do not wish to survive in misery on handouts. They will most likely also have clear and workable ideas how their situation can be improved. In this sense it is important to point out that large-scale, national projects which tend to characterise Western development projects, seldom "work" in Africa. This is so because the basic building block of society in Africa generally remains to be the smaller, village, extended family, or faith community. So "bigger" is seldom "better" in Africa - plans conceived at the centre (polis) are more likely to fail in simple human terms than plans conceived at the periphery (oikos). Despite the glaring poverty and apparent scarcity in so many areas of African life, "life in abundance" is present and happens in networks of solidarity among the poor (cf Saayman 2003:72). These networks are structured by the oikos, not the polis. This is where Christians in the oikoumene can join African Christians to develop an oikonomia, which prioritises humanity - and this is an important future priority of mission and Missiology. 


\section{Bibliography}

Alawode, AO 2013. Constructing mission praxis for sustainable socioeconomic development amongst the rural poor of Oluyole local government, Oyo State, Nigeria. Unpublished D Th thesis, Unisa, Pretoria.

Bate, SC 1995. Inculturation and healing: coping-healing in South African Christianity. Pietermaritzburg: Cluster Publications.

Bosch, DJ 1979. Heil vir die wêreld: die Christelike sending inteologiese perspektief. Pretoria: NG Kerk-Uitgewers.

Bullon, HF 2007. Secular and Technical Perspectives on Development: A Brief History. In: Corrie et al (eds.). Dictionary of Mission Theology: Evangelical Foundation. England: Inter-Varsity Press 2007. 93-96.

Burkey, S 1993. People First: A Guide to Self Reliant Participatory Rural Development. London: Zed Books.

Chambers, R 1983. Rural Development: Putting the Last First. London: Longman Group

Elliott, Jennifer A 2006. An Introduction to Sustainable Development (3 ${ }^{\text {rd }}$ edition). London: Routledge.

Holy Bible, 1996. New Living Translation. Tyndale House Publisher, Inc., Wheaton, Illinois.

Kaulema, D (ed) 2010. Political participation in Zimbabwe. Harare:

African Forum for Social Teachings (AFCAST).

Miller, DL 1998. Discipling the Nations: The Power of Truth to Transform Cultures. Seattle: YWA Publishing

Oyedepo, DO 2005. Towards Empowerment for Change. Lagos, Nigeria: Dominion Publishing House.

Pannell, WE 2002. Empowerment and Peace from Palestine to Cincinnati. Theology, News and Notes. Fuller Theological Seminary. Vol. 49:1, 12-15.

Quaddus, MA (ed.) 2004. Handbook of Sustainable Development Planning: Studies in Modelling and Decision Support. Cheltenham, UK: Edward Elgar Publishing, Inc. 
Saayman, W 1980. Unity and mission: a study of the concept of unity in ecumenical discussion since 1961 and its influence of the world mission of the church. Doctoral thesis, University of Stellenbosch.

Saayman, W (ed.) 1992. Enigste studiegids vir MSA 100-3: Inleiding tot die Sendingwetenskap. Pretoria: Univ. van SA.

Saayman, W 2003. "Ex Africa semper aliquid novi": some random reflections on challenges to Christian mission arising in Africa in the twenty-first century. Mission Studies XX-I, 39, 57-83.

Swart, I 2003. Church, Mission and Development: Revisiting the Pragmatic Debate. Missionalia 31.3 (November 2003) 405-426.

Von Harnack, A 1962. The mission and expansion of Christianity in the first three centuries. New York: Harper \& Brothers (translation of the 1908 German edition).

Wickeri, PL (ed.) 2003. "Toward a kenosis of mission: emptying and empowerment for the church and the world", in Wickeri (ed), Scripture, community and mission. 